\title{
STRES KERJA PERAWAT BERDASARKAN KARAKTERISTIK ORGANISASI DI RUMAH SAKIT
}

\author{
Soep $^{1 *}$ \\ 1. Poltekkes Kemenkes Medan Jurusan Keperawatan, Sumatera Utara 20136, Indonesia \\ *Email:s03p_221270@yahoo.com
}

\begin{abstract}
Abstrak
Stres kerja perawat adalah salah satu masalah manajemen sumber daya manusia di RS yang merupakan kombinasi dari stres saat kerja, karakteristik individu, dan penyebab stres di luar organisasi. Penelitian dengan pendekatan explanatory research ini bertujuan mengetahui pengaruh karakteristik organisasi (aspek keuangan, lingkungan kerja, pengembangan karir, tim kerja, dan tugas) terhadap stres kerja yang dialami perawat di sebuah RS di Medan. Sampel sebanyak 151 diperoleh dengan metode acak sederhana. Data dianalisis melalui uji regresi linear berganda ( $\alpha=0,05$; CI 95\%). Hasil penelitian menunjukkan 59,6\% perawat mengalami stres menengah. Hasil uji regresi logistik menunjukkan bahwa aspek tugas merupakan variabel karakteristik organisasi yang paling berpengaruh terhadap stres kerja perawat dibandingkan variabel lainnya $(p=0,002 ; \alpha=0,05 ;$ dan $\beta=$ 0,274). Rumah sakit diharapkan dapat membuat kebijakan dengan mempertimbangkan aspek yang mempengaruhi stres kerja perawat.
\end{abstract}

Kata kunci: karakteristik organisasi, perawat, stres kerja

\begin{abstract}
Occupational stress of nurse is one of problems on human resources management in hospital which combine of stress at work, individual characteristics, and stress caused by external organization. The purpose of this explanatory research was to examine the influence of organizational characteristic (financial, work environment, career development, teamwork, and duty aspect) toward the occupational stress experienced by the nurses in a hospital in Medan. 151 nurses were selected using simple random sampling method. The data were analyzed by multiple linear regression test ( $\alpha=0.05 ;$; $95 \%)$. The result of study shows that 59.6\% nurses had moderate stress level. The results of logistic regression test shows that the aspect of task is the most influential organizations variable characteristic on occupational stress of nurse compared to other variables ( $p=$ $0.002 ; \alpha=0.05 ;$ and $\beta=0.274$ ). The research suggested the decision maker to consider various aspects influencing occupational stress of nurse in making policies.
\end{abstract}

Keywords: organizational characteristics, nurse, occupational stress

\section{Pendahuluan}

Stres kerja yang dialami perawat akan mempengaruhi kinerjanya yang pada akhirnya akan berdampak pada pelayanan kesehatan kepada pasien.Tenaga keperawatan merupakan tenaga dengan jumlah paling banyak dibanding dengan tenaga kesehatan lainnya dan memberikan pelayanan kepada klien selama 24 jam terus menerus. Hal ini membuat perawat mempunyai posisi yang strategis dan peran penting sebagai ujung tombak pelayanan kesehatan di RS (Gaffar, 1999).

Undang Undang nomor 8/1999 tentang perlindungan konsumen menuntut perawat mampu memberikan pelayanan yang bermutu sesuai dengan standar yang telah ditetapkan. Kondisi yang mencakup tuntutan dari masyarakat yang tinggi ditambah tekanan dari lingkungan kerja termasuk pimpinan dapat menyebabkan perawat mengalami stres kerja (Rasmun, 2004). Beberapa studi menunjukkan bahwa adanya stres kerja yang dialami para perawat yang bekerja di rumah sakit.

Berry dan Lilly (1998) mengutip hasil penelitian Wolfgang terhadap perawat, dokter, dan ahli farmasi yang menemukan bahwa pekerjaan perawat memiliki tingkat stres paling tinggi. Hasil studi Cushway (1996) melaporkan bahwa adanya kecenderungan perawat profesional mengalami stres kronis dan kelelahan. 
Hasil penelitian yang dilakukan oleh Ilmi (2005) di RSUD Ulin Banjarmasin menunjukkan bahwa tingkat stres kerja perawat dengan kategori tinggi sebesar 15\%. Penelitian lain dari Sihombing (2005) di RSU Dr. Pirngadi Medan menemukan bahwa $50 \%$ perawat pelaksana yang bekerja pada shift panjang mengalami stres fisik.

Banyak faktor yang mempengaruhi terjadi stres, diantaranya gaji dan jaminan sosial yang diperoleh. Di RS pemerintah seringkali gaji dan jaminan sosial belum mencukupi kebutuhan sehingga mereka tidak dapat bekerja secara produktif, ini juga dapat menimbulkan masalah kesehatan kerja (Bambang, 2006).

Grainger (1999) mengatakan bahwa petugas kesehatan dalam menjalankan tugasnya menghadapi berbagai hal yang menjadi penyebab stres (stresor) yaitu: (1) menghadapi pasien yang: menderita, sekarat, lumpuh, atau meninggal, (2) keharusan selalu bersikap baik kepada orang yang mungkin tidak disukai, (3) berbicara dengan kerabat pasien, dan bertatap muka langsung dengan orang lain, (4) bekerja dalam waktu yang lama dan dalam shift, (5) melakukan tindakan yang bersifat traumatis, (6) menghadapi kemajuan teknologi, (7) pertanggungjawaban terhadap manusia, (8) risiko yang sangat besar akibat dari keputusan yang salah, (9) risiko penularan penyakit akibat pekerjaan, (10) harapan dan tuntutan masyarakat, (11) risiko kekerasan fisik, serta (12) pengembangan karir yang tidak dapat diramalkan.

Kondisi sebuah organisasi pelayanan kesehatan perlu diperhatikan dan bagaimana hal ini dapat mempengaruhi stres kerja pada perawat yang bekerja didalamnya. Penelitian ini bertujuan untuk menganalisis pengaruh karakteristik organisasi yaitu imbalan jasa, lingkungan kerja, pengembangan karir, tim kerja, dan aspek tugas terhadap stres kerja perawat di sebuah RS di Medan.

\section{Metode}

Penelitian ini menggunakan pendekatan explanatory research yang dilakukan di sebuah RS di
Medan selama empat bulan. Populasi penelitian ini adalah perawat Pegawai Negeri Sipil (PNS) yang berjumlah 427 orang. Sampel dipilih secara acak/ random sederhana sejumlah 151 orang. Karakteristik organisasi dalam penelitian ini adalah ciriciri organisasi atau institusi tempat perawat melakukan pekerjaannya dengan indikator imbalan jasa, lingkungan kerja, pengembangan karir, tim kerja, dan aspek tugas.

Sumber data pada penelitian ini adalah data primer dan data sekunder. Instrumen pengumpulan data dengan menggunakan kuesioner. Data dianalisis dengan metode analisis regresi linear ganda untuk menguji pengaruh karakteristik organisasi yaitu imbalan jasa, lingkungan kerja, pengembangan karir, tim kerja dan aspek tugas terhadap stres kerja perawat di sebuah RS di Medan.

\section{Hasil}

\section{Karakteristik Responden}

Mayoritas responden berusia 20-32 tahun (41,1\%). Responden terbanyak berlatarbelakang pendidikan DIII keperawatan $(66,2 \%)$ dengan masa kerja 12-23 tahun $(38,4 \%)$. Sedangkan berdasarkan jabatan fungsional, mayoritas responden adalah perawat pelaksana $(53,6 \%)$, dan berdasarkan jumlah gaji yang diterima yang terbanyak adalah Rp1.834.000 - Rp2.166.000 (57,7\%). Secara rinci karakteristik responden dapat dilihat di tabel 1.

\section{Karakteristik Organisasi}

Karakteristik dalam penelitian ini adalah ciri-ciri dari organisasi atau institusi tempat perawat melakukan pekerjaannya dengan indikator imbalan jasa, lingkungan kerja, pengembangan karir, tim kerja, dan aspek tugas yang merupakan variabel independen, serta stress kerja yang merupakan variabel dependen.

Pada tabel 2 terlihat bahwa mayoritas responden merasakan imbalan jasa merupakan stressor rendah sebesar 57,0\%, lingkungan kerja dirasakan responden stressor rendah sebesar $37,7 \%$, 
Tabel 1. Karakteristik Responden

\begin{tabular}{|c|c|c|}
\hline Karakteristik & Jumlah & Persentase $(\%)$ \\
\hline \multicolumn{3}{|l|}{ Umur } \\
\hline a. 20-32 tahun & 62 & 41,1 \\
\hline b. $33-45$ tahun & 48 & 31,7 \\
\hline c. $46-56$ tahun & 41 & 27,2 \\
\hline \multicolumn{3}{|l|}{ Pendidikan } \\
\hline a. S1 Perawat & 4 & 2,6 \\
\hline b. S1 Kesmas & 3 & 2,0 \\
\hline c. D4 Perawat & 1 & 0,7 \\
\hline d. D3 Perawat & 100 & 66,2 \\
\hline e. D3 Bidan & 4 & 2,6 \\
\hline f. Perawat Bidan & 3 & 2,0 \\
\hline g. SPK & 25 & 16,6 \\
\hline h. SPRA & 10 & 6,6 \\
\hline \multicolumn{3}{|l|}{ Masa Kerja } \\
\hline a. 1-11 tahun & 48 & 31,8 \\
\hline b. 12-23 tahun & 58 & 38,4 \\
\hline c. 24-36 tahun & 45 & 29,8 \\
\hline Jabatan Fungsional & 81 & 53,6 \\
\hline a. Perawat Pelaksana & 42 & 27,8 \\
\hline b. Perawat Pelaksana lanjutan & 28 & 18,6 \\
\hline \multicolumn{3}{|l|}{ c. Perawat Penyelia } \\
\hline \multicolumn{3}{|l|}{ Gaji } \\
\hline a. Rp1.500.000-Rp1.833.000 & 45 & 29,8 \\
\hline b. Rp1.834.000-Rp2.166.000 & 87 & 57,7 \\
\hline c. Rp2.167.000-Rp2.500.000 & 19 & 12,5 \\
\hline
\end{tabular}

pengembangan karir merupakan stressor rendah sebesar 30,5\%, tim kerja menunjukkan stressor rendah sebanyak $51,7 \%$, dan pada aspek tugas menunjukkan stressor kategori rendah 43,0\%. Hal ini menunjukkan bahwa karakteristik organisasi (imbalan jasa, lingkungan kerja, pengembangan karir, tim kerja, dan aspek tugas) merupakan stressor kategori rendah bagi responden.

Hasil penelitian menunjukkan bahwa stres kerja paling banyak dengan kategori sedang sebanyak $59,6 \%$, dan paling sedikit pada kategori sangat tinggi $(7 \%)$. Hal ini menunjukkan bahwa sebagian besar atau mayoritas responden mengalami stres kerja dengan kategori sedang (dapat dilihat pada tabel 3).

\section{Pengaruh Karakteristik Organisasi terhadap Stres Kerja Perawat}

Pada tabel 4 menunjukkan bahwa secara keseluruhan karakteristik organisasi mempunyai pengaruh terhadap stres kerja perawat di sebuah RS di Medan, yang ditunjukkan oleh nilai $\mathrm{p}<0,05$ masing-masing yaitu variabel imbalan jasa, lingkungan kerja, pengembangan karir, tim kerja, dan aspek tugas ( $\mathrm{p}$ berturut-turut $=0,009 ; 0,010 ; 0,008$; 
$0,042 ; 0,002 ; \alpha=0,05)$. Selain itu, variabel yang paling besar nilai $\beta$ adalah aspek tugas $(\beta=0,274)$, sehingga variabel aspek tugas menjadi variabel paling dominan mempengaruhi stres kerja perawat di sebuah RS di Medan. Sedangkan, variabel yang paling kecil nilai $\beta$ adalah variabel pengembangan karir, yaitu sebesar $\beta=0,180$.

Nilai koefisien determinasi (Adjusted $R$ square) $=$ 0,16 , hal ini menunjukkan bahwa $16 \%$ stres kerja perawat dapat dijelaskan oleh karakteristik organisasi (imbalan jasa, lingkungan kerja, pengembangan karir, tim kerja, aspek tugas), sedangkan sisanya yaitu $84 \%$ dipengaruhi oleh faktor-faktor lain.

\section{Pembahasan}

Stres kerja disebabkan oleh kondisi yang dihadapi dalam melaksanakan pekerjaannya sebagai perawat. Hal ini secara akumulatif akan mempengaruhi pikiran dan psikologisnya yang mengarah pada stres kerja. Keadaan yang dialami perawat tersebut menunjukkan indikasi mengalami stress. Hal ini sejalan dengan pendapat Nursalam (2005) bahwa stress dapat terjadi pada karyawan yang frustasi disebabkan oleh terhambatnya promosi, ketidak jelasan tugas dan wewenang serta ketidak jelasan penilaian atau evaluasi staf dan ketidak puasan gaji yang diterima.

Konsekuensi dari stres kerja tersebut adalah tidak terlaksananya pekerjaan secara maksimal, menyebabkan gangguan psikis yang berat, dan menurunnya produktivitas kerja perawat. Hal ini sejalan dengan pendapat Boenish (2005) bahwa stres dalam jumlah sedikit menguntungkan atau dibutuhkan, tetapi stres yang terlalu lama dapat meletihkan atau merusak sistem tubuh sehingga akan mengakibatkan timbulnya penyakit. Hal tersebut juga sejalan dengan pernyataan Nursalam (2005) bahwa implikasi dari stres kerja perawat akan menyebabkan gangguan kesehatan. Umumnya disebabkan oleh kejenuhan dan beban kerja yang sangat banyak sehingga perawat tidak bisa bekerja secara maksimal.

\section{Pengaruh Imbalan Jasa terhadap Stres Kerja Perawat}

Hasil penelitian menunjukkan bahwa imbalan jasa yang diterima dirasakan perawat menjadi penyebab stres (stresor) yaitu jumlah gaji, tunjangan keluarga, tunjangan fungsional, pemberian insentif, dan tunjangan beras. Hasil penelitian ini selaras dengan pendapat Suryani (2003) dan Ilmi (2005) yang menyatakan bahwa kelelahan mental terjadi disebabkan oleh faktor keuangan (pendapatan yang rendah) dan pemberian upah yang tidak adil.

Namun demikian, terdapat perbedaan pendapat antara hasil penelitian ini dengan pendapat dari Greenberg (2004) yaitu kesulitan keuangan merupakan sumber stres di luar organisasi, sedangkan menurut penelitian ini kesulitan keuangan merupakan sumber stres yang terdapat di dalam organisasi. Hal ini terkait dengan jumlah imbalan jasa (gaji, tunjangan fungsional, tunjangan keluarga, tunjangan beras, dan insentif) yang diterima oleh perawat dirasakan kurang sehingga tidak cukup untuk memenuhi kebutuhan perawat dan keluarganya secara layak.

Penelitian ini menemukan 47,0\% responden yang mengatakan bahwa pemberian gaji kadang dirasakan menjadi beban pikiran. Alasan yang ditulis oleh responden menunjukkan bahwa gaji yang diterima tidak cukup karena harga kebutuhan hidup sehari hari semakin meningkat, seperti kebutuhan pangan, sandang, perumahan, peningkatan harga bahan bakar minyak, dan naiknya biaya transport. Sebagian staf termasuk membantu anggota keluarga lainnya, berbagai keperluan sosial dan adat.

Hal tersebut juga sama dengan pemberian tunjangan fungsional, tunjangan keluarga, dan insentif dengan alasan jawaban responden hampir serupa. Adanya perbedaan hasil penelitian ini, kemungkinan disebabkan oleh perbedaan tingkat perkembangan suatu negara karena Greenberg melakukan penelitian di negara maju sehingga perawat di sana sudah menerima imbalan jasa yang dapat mencukupi seluruh kebutuhan hidupnya dan dapat menjamin untuk hidup layak. 
Tabel 2. Karakteristik Organisasi Responden (Imbalan Jasa, Lingkungan Kerja, Pengembangan Karir, Tim Kerja, dan Aspek Tugas)

\begin{tabular}{|c|c|c|}
\hline Variabel Independen & Jumlah & Persentase (\%) \\
\hline \multicolumn{3}{|l|}{ Imbalan Jasa } \\
\hline a. Sangat rendah & 22 & 14,5 \\
\hline b. Rendah & 86 & 57,0 \\
\hline c. Sedang & 32 & 21,2 \\
\hline d. Tinggi & 9 & 6,0 \\
\hline e. Sangat Tinggi & 2 & 1,3 \\
\hline \multicolumn{3}{|l|}{ Lingkungan Kerja } \\
\hline a. Sangat rendah & 22 & 14,5 \\
\hline b. Rendah & 86 & 57,0 \\
\hline c. Sedang & 32 & 21,2 \\
\hline d. Tinggi & 9 & 6,0 \\
\hline e. Sangat Tinggi & 2 & 1,3 \\
\hline \multicolumn{3}{|l|}{ Penge mbangan Karir } \\
\hline a. Sangat rendah & 36 & 23,8 \\
\hline b. Rendah & 46 & 30,5 \\
\hline c. Sedang & 46 & 30,5 \\
\hline d. Tinggi & 15 & 9,9 \\
\hline e. Sangat Tinggi & 8 & 5,3 \\
\hline \multicolumn{3}{|l|}{ Tim Kerja } \\
\hline a. Sangat rendah & 23 & 15,2 \\
\hline b. Rendah & 78 & 51,7 \\
\hline c. Sedang & 25 & 16,6 \\
\hline d. Tinggi & 15 & 11,9 \\
\hline e. Sangat Tinggi & 8 & 4,6 \\
\hline \multicolumn{3}{|l|}{ Aspek Tugas } \\
\hline a. Sangat rendah & 62 & 41,1 \\
\hline b. Rendah & 65 & 43,0 \\
\hline c. Sedang & 12 & 7,9 \\
\hline d. Tinggi & 8 & 5,3 \\
\hline e. Sangat Tinggi & 4 & 2,6 \\
\hline
\end{tabular}

Sedangkan penelitian yang dilakukan oleh Suryani (2003); Ilmi (2005), yang penelitian ini berada di Indonesia sebagai salah satu negara berkembang, dan juga mengalami krisis ekonomi dalam jangka waktu yang lama sehingga standar imbalan jasa (gaji) Pegawai Negeri Sipil tergolong rendah bila dibandingkan dengan kalkulasi biaya hidup minimal bulanan (Thoha, 2005).

\section{Pengaruh Lingkungan Kerja terhadap Stres Kerja Perawat}

Hasil penelitian menunjukkan 37,7\% termasuk stresor rendah dan 35,8\% stresor sedang. Hasil uji regresi linear berganda menunjukkan lingkungan kerja berpengaruh secara bermakna terhadap stres kerja perawat, yaitu 21,4\% kontribusi variabel lingkungan terhadap stresor stres kerja. 
Stresor sedang ini diindikasikan dari beberapa indikator, yaitu bahwa mayoritas $(54,3 \%)$ menyatakan tidak pernah terganggu dengan kondisi lingkungan kerja di rumah sakit. Hal ini menunjukkan bahwa secara implisit perawat menikmati pekerjaannya dan cenderung tidak mempedulikan kondisi lingkungan rumah sakit, dan berdasarkan pengamatan peneliti rumah sakit tersebut dapat dikatakan nyaman bagi perawat dalam bekerja.

Namun 29,8\% perawat menyatakan bahwa kondisi lingkungan rumah sakit yang dapat menyebabkan penyakit akibat kerja dirasakan menjadi beban pikiran dalam intensitas sering. Hasil penelitian ini selaras dengan pendapat Bambang (2000) yaitu dalam melaksanakan tugas perawat selalu berhadapan dengan lingkungan kerja di rumah sakit yang menimbulkan bahaya potensial yaitu kecelakaan kerja yang disebabkan oleh pekerjaan mengangkat pasien, menyuntik, kuman yang berasal dari pasien dan sebagainya.

Hasil penelitian menunjukkan perawat merasakan bahwa dalam melaksanakan tugasnya sehari hari selalu berhadapan dengan pasien dengan penyakit penyakit yang mengandung kuman tertentu, hal ini dirasakan perawat sebagai sumber stres kerja, sama halnya alat perlindungan diri yang tersedia untuk melindungi diri perawat dari penyakit akibat kerja sangat terbatas.

Hasil penelitian menunjukkan bahwa $38,4 \%$ responden mengatakan bahwa sarana kerja kadangkadang menjadi stresor, 24,5\% responden mengatakan bahwa sarana kerja menjadi stresor kerja dalam

Tabel 3. Karakteristik Organisasi Responden (Stres Kerja) intensitas sering, dan $22,5 \%$ responden mengatakan bahwa sarana kerja selalu menjadi penyebab stres. Dari alasan jawaban responden diketahui bahwa sarana kerja juga dirasakan menjadi sumber stres karena ada beberapa sarana kerja yang tidak layak untuk dipakai, misalnya meja instrumen yang kakinya sudah patah, atau rodanya sudah rusak sehingga kalau dipakai akan menimbulkan bising sehingga menyebabkan pekerjaan perawat tidak lancar. Selain itu, 22,5\% perawat merasakan bahwa resiko kerja seperti berhadapan dengan orang sakit dan keluarga pasien setiap hari dengan segala luapan emosi menjadi selalu menjadi penyebab stres.

\section{Pengaruh Pengembangan Karir terhadap Stres Kerja Perawat}

Hasil penelitian menunjukkan bahwa variabel pengembangan karir menjadi stresor kategori rendah dan sedang adalah sama masing-masing 30,5\%, sedangkan stresor dari pengembangan karir yang sangat tinggi hanya 5,3\%.

Indikator pengembangan karir menunjukkan perawat disamping mengerjakan tugas pokok kadang harus mengerjakan pekerjaan yang tidak sesuai dengan kompetensi, sehingga terkadang menjadi stresor kerja. Dalam penelitian ditemukan 49,0\% perawat menyatakan kadang-kadang kompetensi tidak sesuai dengan pekerjaan menjadi stresor kerja. Selain itu, 24,5\% responden mengatakan proses kenaikan pangkat sering menjadi stresor kerja. Hal ini disebabkan kenaikan pangkat merupakan suatu kebutuhan bagi perawat berstatus PNS,
Variab el Dependen

Stres Kerja

a. Sangat Rendah

b. Rendah

c. Sedang

d. Tinggi

e. Sangat Tinggi n

19

20

90

15

7
Persentase (\%)

12,6

13,2

59,6

9,9

4,6 
tetapi proses pengurusan kepangkatan tersebut membutuhkan waktu yang lama sehingga menjadi penyebab stres kerja perawat. Hasil penelitian ini selaras dengan hasil penelitian oleh Suryani (2003) yaitu peluang peningkatan karir yang rendah dirasakan menyebabkan kelelahan mental bagi perawat.

\section{Pengaruh Tim Kerja terhadap Stres Kerja Perawat}

Hasil penelitian menunjukkan $51,7 \%$ responden mengatakan bahwa tim kerja termasuk stresor kategori rendah. Hal ini tercermin dari $47,0 \%$ responden mengatakan bahwa kadang hubungan dengan rekan kerja menjadi stresor kerja. Selain itu juga terdapat 51,7\% hubungan dengan atasan kadang juga memberikan kontribusi terhadap stres kerja perawat. Hasil uji regresi linear berganda menunjukkan tim kerja mempunyai pengaruh bermakna terhadap stres kerja perawat di sebuah RS di Medan, dan dilihat dari nilai $\beta=0,229$, artinya bila stresor tim kerja dinaikkan sebanyak satu point maka stres kerja akan meningkat sebesar 0,229.

Hasil penelitian ini selaras dengan pendapat ahli antara lain Bailey, Steffen, dan Grout (1996); GrayToft dan Anderson (1996), yang menyatakan bahwa konflik dengan dokter, kurangnya dukungan terhadap staf, konflik dengan perawat lain, kesulitan berhubungan dengan perawat lain, dan staf medis merupakan sumber stres bagi perawat dalam melaksanakan tugasnya.
Berdasarkan penelitian diketahui bahwa dalam melaksanakan pekerjaanya, terutama pada saat pasien dalam keadaan kritis perawat selalu merasa tertekan bila tim kesehatan lain terutama dokter tidak ada di tempat, sulitnya menghubungi dokter juga dirasakan sebagai tekanan oleh perawat. Hubungan perawat dengan rekan kerja baik, hubungan dengan atasan sangat baik dan perawat merasa sangat didukung oleh atasan dalam melaksanakan pelayanan keperawatan.

\section{Pengaruh Aspek Tugas terhadap Stres Kerja Perawat}

Hasil penelitian menunjukkan bahwa mayoritas perawat mengatakan bahwa aspek tugas merupakan stresor rendah 43,0\%. Dan hasil uji menunjukkan variabel aspek tugas merupakan variabel paling dominan berpengaruh secara bermakna terhadap stres, yaitu bila stresor aspek tugas dinaikkan sebanyak 1 point maka stres kerja akan meningkat sebesar 0,274 .

Keadaan tersebut di atas, dapat dijelaskan dalam melaksanakan tugas pokok dan tanggung jawab sebagai perawat merasakan beberapa hal, sebagai stresor kerja. Hal tersebut dapat dijelaskan dari indikator aspek tugas yaitu 57,6\% responden kadang merasakan tugas tambahan menjadi stresor kerja, artinya perawat yang selalu memdapat tugas tambahan akan menimbulkan rasa kesal dan tidak ikhlas dalam bekerja sehingga secara akumulasi akan memberikan kontribusi terhadap stres kerja.

Tabel 4. Pengaruh Karakteristik Organisasi terhadap Stres Kerja Perawat

\begin{tabular}{lccc}
\hline Karakteristik Organisasi & B & SE & p \\
\hline Imbalan jasa & 0,229 & 0,086 & 0,009 \\
Lingkungan kerja & 0,214 & 0,082 & 0,010 \\
Pengembangan karir & 0,180 & 0,067 & 0,008 \\
Tim kerja & 0,229 & 0,112 & 0,042 \\
Aspek tugas & 0,274 & 0,086 & 0,002 \\
(constant) & 0,429 & 0,426 & 0,315 \\
Nilai Adjusted R Square & 0,160 & & \\
\hline
\end{tabular}

*bermakna pada $\alpha=0,05$ 
Selain itu, ditemui $53,6 \%$ responden merasa bekerja pada shift malam kadang dirasakan sebagai stresor kerja, sehingga bila hal ini terakumulasi dalam waktu yang lama dapat dirasakan sebagai beban kerja yang tinggi dan menjadi bagian pencetus terhadap stres kerja.

Hasil penelitian ini selaras dengan pendapat GrayToft dan Anderson (1996); Cox dan Griffiths (2000), bahwa dalam melaksanakan tugas perawat selalu berhadapan dengan penderita yang sakit, dukacita, dan kematian pasien, persiapan yang kurang memadai untuk menghadapi kebutuhan emosional pasien dan keluarga, serta tenggat.

\section{Kesimpulan}

Semua karakteristik organisasi yang diujikan berpengaruh terhadap stress kerja. Aspek tugas merupakan stresor paling dominan yang berpengaruh terhadap stres kerja perawat. Imbalan jasa, lingkungan kerja, pengembangan karir, dan tim kerja juga berpengaruh pada stress kerja perawat. Karakteristik organisasi ini merupakan stressor kategori rendah bagi perawat di sebuah RS Medan.

Penting untuk meningkatkan kesejahteraan bagi perawat, berupa peningkatan insentif, penyediaan alat perlindungan diri, pemeriksaan kesehatan secara berkala, dan penyediaan peralatan kerja yang memadai. Upaya pengembangan karir perawat, pimpinan RS perlu mengalokasikan dana untuk biaya pendidikan dan pelatihan bagi perawat, dan peninjauan ulang perihal kenaikan pangkat (MS, HH, INR).

\section{Referensi}

Bambang. (2000). Stres dan keselamatan kerja. Jakarta: Penerbit Universitas Indonesia.

Bailey, J.T., Steffen, S.M., \& Grout, J.W. (1996). The stress audit: Identifying the stressor of ICU nursing. J Nurs Educ, 19 (6), 15 - 25.

Berry, L.M. (1998). Psychology at work: An introduction to industrial \& organizational psychology (2nd Ed.). Boston: McGraw-Hill.
Boenisch, E.W., \& Haney, C.M. (2005). The stress owner's manual: Meaning, balance, and health in your life (2nd Ed.). Atascadero: Impact Publisher.

Cox, T., \& Griffiths, A. (2000). Work related stress in nursing: Controlling the risk to health. Geneva: International Labour Office.

Cushway, D. (1996). Development of stress scale for mental health professionals. British Journal of Clinical Psychology, 32, 190 - 197.

Gaffar, LOJ. (1999). Pengantar keperawatan profesional. Jakarta: Penerbit EGC.

Gray-Toft, P., \& Anderson, JG. (1996). Stress among hospital nursing staff: Its causes and effects. Social Science \& Medicine, 15 (5), 639 - 647.

Greenberg, J. S. (2004). Comprehensive stress management (8th Ed.). New York : McGraw-Hill.

Grainger, C. (1999). Stress survival guide: Mengatasi stres bagi para dokter (Alih bahasa: Manfred Himawan). Jakarta: Hipokrates. (Cet. Asli 1994.)

Ilmi, B. (2005). Pengaruh stres kerja terhadap prestasi kerja di RSUD Ulin Banjarmasin (Laporan penelitian, tidak dipublikasikan). Fakultas Ilmu Keperawatan Universitas Indonesia, Jakarta.

Nursalam. (2002). Manajemen keperawatan: Aplikasi dalam keperawatan professional. Jakarta: Salemba Medika.

Rasmun. (2004). Stres, koping, dan adaptasi: Teori dan pohon masalah keperawatan. Jakarta: Sagung Seto.

RSU Dr. Pirngadi Medan. (2006). Rencana Strategis Rumah Sakit. RSU Dr.Pirngadi Medan.

Sihombing, H. (2005). Hubungan lama hari pergantian shift dengan stress pada perawat pelaksana (Skripsi, Program Studi Ilmu Keperawatan Universitas Sumatera Utara). Universitas Sumatera Utara, Medan.

Suryani. (2003). Conceptual understanding and its evidence in mental Health nurse. Nursing of Padjajaran University, 31 (6), $602-620$.

Thoha, M. (2005). Manajemen kepegawaian sipil di Indonesia. Yogyakarta: Kencana. 